\title{
Peningkatan Perilaku Disiplin Anak Melalui Metode Pembiasaan di Taman Kanak-kanak Islam Terpadu Insan Kamil kelompok B1 usia 5-6 tahun
}

\author{
Rumiati La Jaga ${ }^{1}$, Andi Agustan Arifin ${ }^{2}$ \\ ${ }^{1,}$ TK IT Insan Kamil Halmahera Selatan, ${ }^{2,}$ Universitas Khairun \\ Halmahera Selatan, Jl. Bandara Baabullah, Kota Ternate Maluku Utara \\ Email: thata cemanizt88@yahoo.com ${ }^{1}$, agus arizona@yahoo.co.id ${ }^{2}$
}

Naskah diterima: 1 Maret 2019, direvisi: 22 Maret 2019, diterbitkan: 30 Maret 2019

\section{Abstrak}

Tujuan penelitian ini adalah untuk mengetahui metode pembiasaan dapat meningkatkan perilaku disiplin anak pada TK IT Insan Kamil Kelompok B1. Penelitian ini merupakan Penelitian Tindakan Kelas (PTK). Subjek penelitian sebanyak 19 orang. Rancangan tahap penelitian meliputi Perencanaan, Aksi atau pelaksanaan, observasi dan refleksi Teknik pengumpulan data yang digunakan adalah observasi, Teknik analisis data dalam penelitian ini yakni analisis deskriptif dengan berdasar pada hasil observasi. Hasil yang diperoleh bahwa Penerapan metode pembiasaan dapat meningkatkan perilaku kedisiplinan anak di taman kanak-kanak Islam Terpadu Insan Kamil pada Kelompok B1 Kabupaten Halmahera Selatan. Pada siklus I dari hasil observasi menunjukkan bahwa rata-rata $20 \%$ kemampuan anak belum berkembang dan 43,5\% kemampuan anak mulai berkembang sedangkan pada siklus II terjadi peningkatan, kemampuan anak berkembang sesuai harapan sebesar 56,27\% dan berkembang sangat baik sebesar 26,75\%. Dengan demikian, penerapan metode pembiasaan dapat meningkatkan perilaku disiplin anak di taman kanak-kanak B1 TK IT Insan Kamil.

Kata kunci: perilaku disiplin, metode pembiasaan

\begin{abstract}
The purpose of this study is to know the method of habituation can improve the behavior of children's discipline in Kindergarten IT Insan Kamil Group B1. This research is a Classroom Action Research (PTK). Research subjects were 19 people. The design stage of the study includes planning, action or implementation, observation and reflection Technique of collecting data used is observation. The results obtained that the application of methods of habituation can improve the behavior of children's discipline in Kansan Integrated Islamic
\end{abstract}


Kindergarten in Group B1 of South Halmahera Regency. In the first cycle of the observation results showed that the average of $20 \%$ of the ability of children has not developed and 43,5\% of the ability of children began to develop while in cycle II there is an increase, the ability of children to develop as expectations of 56,27\% and $26,75 \%$ very good growth.

Keywords: discipline, method of habituation

\section{Pendahuluan}

Pendidikan merupakan suatu hal yang sangat penting dan tidak dapat dipisahkan dari kehidupan seseorang baik dalam keluarga, masyarakat, dan bangsa. Kemajuan suatu bangsa ditentukan oleh tingkat keberhasilan pendidikan. Negara Indonesia sebagai negara berkembang dalam pembangunan membutuhkan sumber daya manusia yang dapat diandalkan, Pembangunan manusia Indonesia pada dasarnya merupakan pengamalan nilainilai Pancasila. Pembangunan ini meliputi pembangunan materiil dan spiritual.

Dalam suatu bangsa, keberhasilan pendidikan akan dicapai apabila ada usaha untuk meningkatkan mutu pendidikan bangsa itu sendiri. Melalui pendidikan diharapkan adanya perkembangan fisik, mental, sosial, dan emosional untuk meningkatkan taraf kehidupan dan kebudayaan bagi pesarta didik. Pendidikan dilaksanakan di lingkungan keluarga, sekolah, dan masyarakat. Salah satu lembaga yang paling penting dalam pelaksanaan pendidikan adalah sekolah. Dalam hal ini tugas sekolah adalah mengembangkan potensi, bakat, kemampuan, dan minat sehingga anak menjadi manusia yang bertaqwa terhadap Tuhan Yang Maha Esa, percaya diri sendiri, berdisiplin, dan bertanggung jawab terhadap diri sendiri dan masyarakat.

Di lingkungan sekolah, gurulah yang memegang peranan penting dalam mengembangkan anak. Tugas guru di sekolah yaitu membina dan mendidik anak didiknya selain belajar dengan baik, tetapi juga harus membina dan mengarahkan anak didiknya untuk bersikap, berperilaku dan berdisiplin dengan baik. Kondisi sekolah yang aman dan tertib dapat dicapai jika guru mampu mengatur dan mengarahkan murid untuk senantiasa mematuhi peraturan atau tata tertib sekolah yang berlaku.

Sikap disiplin tidak secara otomatis dibawa sejak lahir. Disiplin (sikap moral) dibentuk oleh lingkungannya melalui pola asuh orang tua, guru, dan orang-orang dewasa disekitar diri individu. Melalui penanaman disiplin sejak dini, diharapkan anak dapat berperilaku cara-cara yang sesuai dengan standar kelompok, sosial dan kelompok budaya dimana anak itu berada. 
Definisi lain dikemukakan oleh Afrizal (2010:54) yang menyatakan bahwa "disiplin dapat dikatakan sebagai alat pendidikan bagi anak, sebab dengan disiplin anak dapat membentuk sikap teratur dan mentaati norma aturan yang ada. Untuk itu disiplin sudah bisa dibiasakan dalam kehidupan anak sejak usia dini”. Pembiasaan merupakan titik tombak dalam mengembangkan disiplin anak usia dini. Menurut Hasnida (2014 :15) disiplin yaitu mencakup pengajaran, bimbingan atau dorongan yang dilakukan oleh orang dewasa, tujuannya menolong anak belajar untuk hidup sebagai makhluk sosial dan untuk mencapai pertumbuhan serta perkembangan mereka yang optimal. Penerapan disiplin yang utama adalah tidak adanya sikap permusuhan, yang ada hanyalah keinginan untuk membentuk menjadi anak yang berguna dan baik. Untuk mewujudkan proses pendisplinan menjadi permanen maka perlu pembiasaan yang secara terus menerus sehingga menjadi kebiasaan yang baik. Pembiasaan dilakukan agar anak-anak terbiasa melakukan sesuatu hal dengan tertib dan teratur sejak dini. Purwanto (1993:224) menyatakan "Pembiasaan adalah salah satu langkah dalam proses menanamkan disiplin terutama bagi anak-anak yang masih kecil”. Proses pembentukan sikap dan perilaku yang relatif menetap dan bersifat otomatis melalui proses pembelajaran yang berulang-ulang. Untuk menanamkan pembiasaan terhadap anak usia Taman Kanak-Kanak, yaitu usia 4-6 tahun bersifat, dan dapat dilaksanakan secara rutin, spontan dan terprogram. (Depdiknas, 2007:4). penerapan pembiasaan untuk berperilaku disiplin tidak mesti dilakukan secara otoriter. Bagi anak, kebiasaan- kebiasaan baik harus dipupuk sedini mungkin, karena bila terlanjur dewasa niscaya menemui kesulitan sebab pada diri anak remaja tersebut mungkin telah tambah pula kebiasaan tertentu yang sudah melekat padanya.

dalam upaya mengembangkan disiplin maka seyogyanya guru memilki pemahaman tentang peraturan atau norma-norma dan dapat berperilaku sesuai dengan norma atau peraturan tersebut. Disamping dapat merealisasikannya, guru juga harus mampu mentransformasikan norma tersebut kepada anak didiknya. Sehingga antara pendidik dan peserta didik mampu hidup selaras dengan lingkungannya.

Namun demikian, hal tersebut tampaknya belum sepenuhnya tercapai karena tidak sedikit guru yang belum mampu mendisiplinkan anak di lingkungan sekolah. Anak terkadang hanya difokuskan pada pembelajaran mengenai materi-materi pelajaran dari buku. Sehingga kemampuan anak dalam hal pelajaran tidak sejalan dengan perilaku yang baik dan berdisiplin sesuai dengan nilai-nilai yang dijunjung tinggi oleh agama, pemerintah, dan masyarakat pada umumnya. 
Hal ini dilihat terjadi pula di Taman Kanak-kanak Insan Kamil Kabupaten Halmahera Selatan. Berdasarkan hasil observasi pada pertengahan bulan Juni, menunjukkan bahwa beberapa murid di Taman Kanak-kanak cenderung tidak disiplin. Anak masih sering datang terlambat bahkan tidak datang ke sekolah. Adapula yang tidak mencuci tangan sebelum makan dan tidak merapikan mainan setelah bermain.

Untuk dapat menjadikan anak berperilaku disiplin, guru dapat menerapkan pengembangan perilaku melalui pembiasaan sejak dini. Pembiasaan merupakan bagian penting dalam tahapan penalaran prakonvensional dimana anak mula-mula mengembangkan keterampilan hidupnya lebih banyak bergantung pada faktor eksternal.

\section{Metodologi}

Penelitian ini merupakan jenis penelitian tindakan kelas (PTK) yang berbentuk daur ulang, yaitu: perencanaan, aksi atau pelaksanaan tindakan, observasi dan refleksi yang menggunakan pendekatan kualitatif. Penelitian ini akan mengkaji tentang peningkatan perilaku disiplin anak melalui metode pembiasaan terhadap pada TK IT Insan Kamil Kabupaten Halmahera Selatan. Penelitian ini dilakukan di Taman Kanak-Kanak Islam Terpadu Insan Kamil yang beralamat di Jalan Raya Hidayat Desa Tomori Kec. Bacan Kabupaten Halmahera Selatan. Subjek penelitian ini adalah murid kelompok B1 Taman Kanak-kanak Insan Kamil Kabupaten Halmahera Selatan yang terdiri dari 8 laki-laki dan 11 perempuan dengan total subjek sebanyak 19 orang pada tahun ajaran 2017/2018.

Penelitian tindakan kelas ini berbentuk siklus dan berdaur ulang. Prosedurnya meliputi: perencanaan, aksi atau pelaksanaan, observasi, dan refleksi. Penelitian ini terdiri dari 2 siklus, dimana setiap siklus diadakan refleksi untuk mengetahui peningkatan disiplin anak melalui pembiasaan.

Teknik pengumpulan data penelitian menggunakan observasi. Kegiatan observasi atau pengamatan merupakan kegiatan mengamati proses kegiatan latihan pembiasaan anak untuk meningkatkan kedisiplinannya. Perilaku disiplin yang ingin diamati adalah Datang tepat waktu di sekolah, berdoa sebelum dan sesudah makan, mencuci tangan dan merapikan tempat bermain. Kegiatan observasi ini dilakukan dengan menggunakan format observasi. 


\section{Hasil dan Diskusi}

Untuk menggambarkan kondisi awal perilaku disiplin anak di Taman Kanak-Kanak Insan Kamil Kabupaten Halmahera Selatan, diadakan observasi pada 21 Agustus 2017 dengan cara mengamati perilaku anak dalam hal kebiasaan berdoa sebelum dan sesudah makan, tepat waktu datang ke sekolah, kebiasaan mencuci tangan sebelum dan sesudah makan, serta kebiasaan merapikan mainan setelah bermain. Hasil observasi tersebut digambarkan pada tabel di bawah ini.

Tabel 1. Kondisi Awal Perilaku Disiplin Anak Taman Kanak Kanak Insan Kamil Kabupaten Halmahera Selatan

\begin{tabular}{|c|c|c|c|c|}
\hline \multirow[b]{2}{*}{ Nama } & \multicolumn{4}{|c|}{ Indikator Perilaku Disiplin Anak } \\
\hline & $\begin{array}{l}\text { Hadir tepat } \\
\text { waktu }\end{array}$ & $\begin{array}{c}\text { Berdoa sebelum } \\
\text { \& sesudah } \\
\text { makan }\end{array}$ & $\begin{array}{l}\text { Mencuci tangan } \\
\text { sebelum \& } \\
\text { sesudah makan }\end{array}$ & $\begin{array}{c}\text { Merapikan } \\
\text { mainan setelah } \\
\text { bermain }\end{array}$ \\
\hline Alya & $\mathrm{BSH}$ & $\mathrm{BSH}$ & MB & MB \\
\hline Azfar & $\mathrm{BB}$ & $\mathrm{BB}$ & MB & $\mathrm{BB}$ \\
\hline Anisa & $\mathrm{BB}$ & $\mathrm{BB}$ & MB & $\mathrm{BB}$ \\
\hline Aira & MB & MB & $\mathrm{BB}$ & MB \\
\hline Erfandi & MB & $\mathrm{BB}$ & $\mathrm{BB}$ & $\mathrm{BB}$ \\
\hline Zidan & MB & $\mathrm{BB}$ & $\mathrm{BB}$ & $\mathrm{BB}$ \\
\hline Zidna & MB & $\mathrm{BB}$ & $\mathrm{BB}$ & $\mathrm{MB}$ \\
\hline Nadira & BSH & $\mathrm{BB}$ & MB & MB \\
\hline Nijar & MB & MB & $\mathrm{BB}$ & $\mathrm{BB}$ \\
\hline Sofyan & MB & $\mathrm{BB}$ & $\mathrm{BB}$ & $\mathrm{BB}$ \\
\hline Nifsah & MB & $\mathrm{MB}$ & $\mathrm{BB}$ & $\mathrm{MB}$ \\
\hline Aqifa & $\mathrm{BSH}$ & MB & $\mathrm{BSH}$ & MB \\
\hline Bagas & $\mathrm{BB}$ & $\mathrm{MB}$ & $\mathrm{MB}$ & $\mathrm{MB}$ \\
\hline Yasmin & $\mathrm{BB}$ & $\mathrm{BB}$ & $\mathrm{BB}$ & MB \\
\hline Jihan & $\mathrm{BSH}$ & MB & MB & MB \\
\hline Zahira & MB & $\mathrm{MB}$ & BSH & $\mathrm{MB}$ \\
\hline Muthia & $\mathrm{BSH}$ & MB & MB & $\mathrm{MB}$ \\
\hline Fais & $\mathrm{BB}$ & $\mathrm{BB}$ & $\mathrm{BB}$ & $\mathrm{BB}$ \\
\hline Alesya & $\mathrm{BSH}$ & $\mathrm{BSH}$ & MB & MB \\
\hline
\end{tabular}

Data hasil observasi di atas menunjukkan bahwa perilaku disiplin anak masih kurang. Terlihat bahwa kedisplinan dalam kehadiran anak masih ada yang belum berkembang. Ada 5 anak diantaranya masih belum berkembang, 8 anak yang mulai berkembang dan 6 anak yang sudah berkembang sesuai harapan. Kedisiplinan anak dalam berdoa sebelum dan sesudah masih perlu ditingkatkan. Ada 9 anak yang kedisiplinannya belum berkembang, 8 anak yang sudah mulai berkembang dan 2 anak yang sudah berkembang sesuai harapan. Hal tersebut terlihat pula dalam hal kedisiplinan mencuci tangan sebelum dan sesudah makan. Ada 9 anak yang kedisiplinannya dalam mencuci tangan belum berkembang dan 8 anak lainnya sudah 
mulai berkembang serta 2 anak yang berkembang sesuai harapan. Perilaku anak dalam merapikan mainan setelah bermain juga masih perlu ditingkatkan. Ada 7 anak yang kedisiplinannya belum berkembang dan 12 anak yang sudah mulai berkembang.

Dari hasil obervasi awal disimpulkan bahwa perilaku disiplin anak perlu ditingkatkan melalui metode pembiasaan. Melalui metode pembiasaan diharapkan perilaku disipin anak bisa berkembang dengan sangat baik.

Dalam penelitian ini, peneliti membagi 2 siklus yaitu siklus I dan siklus II. Kegiatan pembelajaran pembiasaan dalam setiap siklus dilakukan melalui kegiatan terprogram hingga akhirnya diharapkan menjadi kegiatan rutin setiap harinya. Selain itu, diterapkan pula kegiatan spontan dimana guru secara langsung memberikan arahan/menegur ketika anak tidak disiplin sehingga anak dapat merubah perilakunya secara langsung. Adapun uraian pelaksanaan kegiatan pada setiap siklus dijelaskan sebagai berikut:

\section{Paparan Siklus I}

Siklus I dilaksanakan pada minggu ke 3 bulan Agustus 2017, yakni tanggal 28 Agustus30 Agustus 2017. Kegiatan observasi dilakukan setelah kegiatan terprogram di laksanakan. Observasi dilakukan selama 1 pekan untuk mengamati apakah ada perubahan sikap dan perilaku anak setelah menerapkan metode pembiasaan dilakukan dan untuk mengetahui apakah anak telah rutin menerapkannya di sekolah baik sebelum pelajaran dimulai, pada saat kegiatan pembelajaran, dan setelah pembelajaran berakhir.

Selama observasi dilakukan menunjukkan bahwa perilaku disiplin anak cenderung dilakukan secara rutin seperti yang telah diarahkan oleh guru. Namun, beberapa diantara masih tetap tidak menerapkan perilaku disiplin. Adapun uraian hasil observasinya sebagai berikut.

Tabel 2. Rekapitulasi Hasil Observasi Tindakan Siklus I

\begin{tabular}{|c|c|c|c|c|c|c|c|c|c|}
\hline \multirow{3}{*}{ Kategori } & \multicolumn{8}{|c|}{ Aspek yang diamati } & \multirow{3}{*}{$\begin{array}{c}\text { Rerata } \\
(\%)\end{array}$} \\
\hline & \multicolumn{3}{|c|}{1} & \multicolumn{2}{|c|}{2} & \multicolumn{2}{|l|}{3} & \multirow{2}{*}{$\begin{array}{l}4 \\
\% \\
\end{array}$} & \\
\hline & $f$ & $\%$ & $F$ & $\%$ & $f$ & $\%$ & $F$ & & \\
\hline $\begin{array}{l}\text { Berkembang } \\
\text { Sangat Baik }\end{array}$ & 0 & 0 & 1 & 5 & 2 & 10 & 2 & 10 & 6,25 \\
\hline $\begin{array}{l}\text { Berkembang } \\
\text { Sesuai Harapan }\end{array}$ & 8 & 42 & 4 & 21 & 8 & 42 & 3 & 16 & 30.25 \\
\hline $\begin{array}{c}\text { Mulai } \\
\text { Berkembang }\end{array}$ & 8 & 42 & 9 & 47 & 5 & 27 & 11 & 58 & 43.5 \\
\hline $\begin{array}{c}\text { Belum } \\
\text { Berkembang }\end{array}$ & 3 & 16 & 5 & 27 & 4 & 21 & 3 & 16 & 20 \\
\hline Jumlah & 19 & 100 & 19 & 100 & 19 & 100 & 19 & 100 & 100 \\
\hline
\end{tabular}


(a) Pada indikator disiplin dalam kehadiran, ada 3 anak (16\%) yang belum hadir tepat waktu, 8 anak (42\%) yang kehadiran tepat waktunya mulai berkembang, 8 (42\%) anak yang sudah berkembang sesuai harapan, dan belum ada anak yang perilakunya berkembang sangat baik.

(b) Pada indikator berdoa sebelum dan sesudah makan, ada 5 anak (27\%) yang perilakunya belum berkembang. Mereka tidak berdoa sebelum dan sesudah makan. Ada 9 anak (47\%) yang perilakunya mulai berkembang, 4 anak (21\%) yang berkembang sesuai harapan dan 1 anak (5\%) yang sudah berkembang sangat baik. Dia sudah dapat melakukannya secara mandiri.

(c) Pada indikator mencuci tangan sebelum dan sesudah makan, ada 4 anak (21\%) yang perilakunya belum berkembang. Anak tidak mencuci tangan sebelum dan sesudah makan. Ada 5 anak (27\%) yang perilakunya mulai berkembang, 8 anak (42\%) yang perilakunya sudah berkembang sesuai harapan, serta 2 anak yang perilakunya sudah berkembang dengan sangat baik.

(d) Pada indikator merapikan mainan setelah bermain, ada 3 anak (16\%) yang perilakunya belum berkembang. Mereka tidak merapikan sama sekali mainannya setelah bermain. Ada 11 anak (58\%) yang perilakunya sudah mulai berkembang. Mereka melakukannya dengan bantuan bimbingan guru. Ada 3 anak (16\%) yang perilakunya sudah berkembang sesuai harapan serta 2 anak (10\%) yang perilakunya sudah berkembang dengan sangat baik.

Setelah pelaksanaan tindakan pada siklus I berlangsung, maka peneliti bersama observer melakukan diskusi tentang proses kegiatan yang telah dilakukan. Dari pertemuan itu diperoleh kesimpulan awal tentang beberapa hal yang belum maksimal dari pelaksanaan siklus I. Pada siklus I terjadi perubahan dalam kebiasaan-kebiasaan anak kelompok B. Anakanak sudah mulai hadir tepat waktu di sekolah. Namun masih ada sebagian kecil yang tidak hadir tepat waktu. Mereka juga sudah mulai menerapkan kebiasaan berdoa sebelum dan sesudah makan. Pada saat sebelum dan sesudah makan, anak juga sudah mulai menerapkan kebiasaan mencuci tangan. Meskipun demikian, masih ada sebagian dari mereka yang masih cenderung kurang disiplin. Mereka terkadang mencuci tangan tapi tidak bersih dan tidak menggunakan sabun. Bahkan sebelum makan, ada anak yang tidak berdoa. 
Berdasarkan hasil analisis tersebut, maka peneliti menarik kesimpulan sementara dari pelaksanaan siklus I dimana telah terjadi perubahan pada anak namun peneliti akan melanjutkan ke tahap berikutnya melalui pelaksanaan siklus II.

\section{Paparan Siklus II}

Uraian pelaksanaan siklus II juga melalui 4 tahap yaitu perencanaan, pelaksanaan, observasi dan evaluasi. Adapun uraian pelaksanaannya sbeagai berikut: Siklus II dilaksanakan pada minggu ke 1 bulan September 2017, yakni tanggal 04 September - 06 September 2017. Kegiatan observasi dilakukan setelah kegiatan terprogram di laksanakan. Observasi dilakukan selama 1 pekan untuk mengamati apakah ada perubahan sikap dan perilaku anak setelah menerapkan metode pembiasaan dilakukan dan untuk mengetahui apakah anak telah rutin menerapkannya di sekolah baik sebelum pelajaran dimulai, pada saat kegiatan pembelajaran, dan setelah pembelajaran berakhir. Selama observasi dilakukan menunjukkan bahwa perilaku disiplin anak lebih meningkat dari hari-hari sebelumnya. Hanya sedikit diantaranya yang masih perlu bimbingan. Adapun uraian hasil observasinya sebagai berikut:

Tabel 3. Rekapitulasi Hasil Observasi Tindakan Siklus II

\begin{tabular}{|c|c|c|c|c|c|c|c|c|c|}
\hline \multirow{3}{*}{ Kategori } & \multicolumn{8}{|c|}{ Aspek yang diamati } & \multirow{3}{*}{$\begin{array}{c}\text { Rerata } \\
\%\end{array}$} \\
\hline & \multicolumn{3}{|c|}{1} & \multicolumn{2}{|l|}{2} & \multicolumn{2}{|l|}{3} & \multirow{2}{*}{$\begin{array}{l}4 \\
\%\end{array}$} & \\
\hline & $f$ & $\%$ & $F$ & $\%$ & $f$ & $\%$ & $f$ & & \\
\hline $\begin{array}{c}\text { Berkembang Sangat } \\
\text { Baik }\end{array}$ & 5 & 27 & 4 & 21 & 6 & 32 & 5 & 27 & 26,75 \\
\hline $\begin{array}{c}\text { Berkembang Sesuai } \\
\text { Harapan }\end{array}$ & 10 & 52 & 12 & 63 & 11 & 58 & 10 & 52 & 56,25 \\
\hline Mulai Berkembang & 3 & 16 & 3 & 16 & 2 & 10 & 3 & 16 & 14,5 \\
\hline Belum Berkembang & 1 & 5 & 0 & 0 & 0 & 0 & 1 & 5 & 2,5 \\
\hline Jumlah & 19 & 100 & 19 & 100 & 19 & 100 & 19 & 100 & 100 \\
\hline
\end{tabular}

(a) Pada indikator disiplin dalam kehadiran, ada 1 anak (5\%) yang belum hadir tepat waktu, 3 anak (16\%) yang kehadiran tepat waktunya mulai berkembang, 10 (52\%) anak yang sudah berkembang sesuai harapan, dan ada 5 anak (27\%) yang perilakunya berkembang sangat baik. Dalam arti bahwa anak sudah dapat melakukannya secara rutin dan mandiri.

(b) Pada indikator berdoa sebelum dan sesudah makan, tidak ada anak (0\%) yang perilakunya belum berkembang. Ada 3 anak (16\%) yang perilakunya mulai berkembang, 12 anak (63\%) yang berkembang sesuai harapan dan 4 anak (21\%) yang sudah berkembang sangat baik. Dia sudah dapat melakukannya secara mandiri. 
(c) Pada indikator mencuci tangan sebelum dan sesudah makan, tidak ada anak $(0 \%)$ yang perilakunya belum berkembang. Ada 2 anak (10\%) yang perilakunya mulai berkembang, 1 anak (58\%) yang perilakunya sudah berkembang sesuai harapan, serta 6 anak $(32 \%)$ yang perilakunya sudah berkembang dengan sangat baik.

(d) Pada indikator merapikan mainan setelah bermain, ada 1 anak (5\%) yang perilakunya belum berkembang. Mereka tidak merapikan sama sekali mainannya setelah bermain. Ada 3 anak (16\%) yang perilakunya sudah mulai berkembang. Mereka melakukannya dengan bantuan bimbingan guru. Ada 10 anak (52\%) yang perilakunya sudah berkembang sesuai harapan serta 5 anak (27\%) yang perilakunya sudah berkembang dengan sangat baik.

Setelah pelaksanaan tindakan pada siklus II berlangsung, maka peneliti bersama observer melakukan diskusi tentang proses kegiatan yang telah dilakukan. Dari pertemuan itu diperoleh kesimpulan tentang beberapa hal pelaksanaan siklus II. Pada siklus II terjadi perubahan dalam kebiasaan-kebiasaan anak kelompok B. Anak-anak sudah banyak yang hadir tepat waktu di sekolah. Namun hanya sebagian kecil yang tidak hadir tepat waktu. Mereka juga sudah mulai menerapkan kebiasaan berdoa sebelum dan sesudah makan. Pada saat sebelum dan sesudah makan, anak juga sudah menerapkan kebiasaan mencuci tangan. Hal tersebut menunjukkan indikator keberhasilan guru dalam menerapkan pembiasaan pada anak. Meskipun begitu, anak tetap perlu didampingi dan diarahkan agar kebiasaan-kebiasaan disiplin dapat selalu diterapkan secara terus menerus hingga akhirnya tidak perlu mendapatkan teguran lagi.

Berdasarkan pelaksanaan tindakan yang telah dilakukan oleh peneliti dalam penelitian melalui penerapan metode pembiasaan untuk meningkatkan perilaku disiplin anak kelompok B di TK Insan Kamil telah menunjukkan perubahan perilaku.

Dalam lingkungan sekolah, anak ditempatkan sebagai subjek dan sekaligus objek didik. Sebagai subjek didik anak akan aktif sesuai dengan minat, bakat dan potensinya dan ditempatkan secara layak, manusiawi serta dihargai oleh setiap komponen pengajaran. Sedangkan sebagai objek didik siswa harus menerima pengajaran berupa pengetahuan, nilai moral dan keterampilan. Peranan guru dalam menciptakan situasi sekolah yang aman dan tertib, haruslah yang dapat mendorong anak untuk berdisiplin diri dalam bersikap, berperilaku dan belajarnya karena terciptanya suasana yang kondusif bagi berlangsungnya pembelajaran yang efektif di dalam kelas dapat terjadi dengan adanya disiplin dalam diri anak. 
Kedisiplinan yang ada dalam diri anak tidak serta merta langsung terpenuhi namun dapat diupayakan melalui pembiasaan baik dengan kegiatan teladan, kegiatan spontan, dan kegiatan terprogram yang akhirnya akan menjadi kegiatan rutin setiap harinya. Seperti halnya pada penelitian ini, peneliti menerapkan pembiasaan melalui 2 kegiatan yakni kegiatan terprogram dan kegiatan spontan. Kegiatan terprogram diselipkan pada kegiatan pembelajaran sedangkan kegiatan spontan secara langsung diterapkan jika anak menunjukkan perilaku ketidakdisiplinan pada setiap kegiatan mulai datang ke sekolah hingga pulang sekolah. Hal ini sejalan dengan pendapat Depdiknas (2007) yang menyatakan bahwa kegiatan terprogram adalah kegiatan yang dalam pelaksanaannya terlebih dahulu diawali dengan adanya perencanaan atau program dari guru dalam kegiatan pembelajaran (perencanaan semester, satuan kegiatan mingguan dan satuan kegiatan harian) di TK, misalnya: makan bersama, menggosok gigi, cara berpakaian, menjaga kebersihan lingkungan, dan lain-lain.

Pada penelitian ini, indikator kedisiplinan yang diharapkan dapat tercapai yaitu disiplin waktu (hadir tepat waktu), disiplin berdoa sebelum dan sesudah makan, disiplin mencuci tangan sebelum dan sesudah makan, serta disiplin merapikan kembali mainan setelah bermain. Anak diharapkan terbiasa hadir tepat waktu di sekolah, mencuci tangan sebelum dan sesudah makan, berdoa sebelum dan sesudah makan, merapikan mainan setelah bermain, Perubahan perilaku disiplin anak diketahui dengan cara observasi peneliti secara langsung terhadap bagaimana anak berperilaku setiap harinya.

Menurut Syarbini (2014: 87) pembiasaan yang dilakukan sejak dini sejak kecil akan membawa kegemaran dan kebiasaan tersebut menjadi semacam adat kebiasaan sehingga menjadi bagian tidak terpisahkan dari kepribadiannya. Dalam pembinaan sikap (karakter), metode pembiasaan sebenarnya cukup efektif. Anak-anak yang dibiasakan bangun pagi, akan bangun pagi sebagai kebiasaan. Sejalan dengan pendapat tersebut Amin (2015: 54) mengemukakan bahwa tujuan metode pembiasaan adalah agar anak memperoleh sikap-sikap dan kebiasaan-kebiasaan baru yang lebih tepat dan positif dalam arti selaras dengan kebutuhan ruang dan waktu (kontekstual). Selain itu, arti tepat dan positif di atas ialah selaras dengan norma dan tata nilai moral yang berlaku, baik yang bersifat religius maupun tradisional dan kultural.

Untuk membantu anak yang belum menunjukkan adanya perkembangan perilaku disiplin, guru dan pihak sekolah melakukan komunikasi kepada orang tua murid dan memberikan perhatian kepada anak tersebut. 
Dari hasil penelitian dapat disimpulkan bahwa metode pembiasaan dapat meningkatkan perlaku disiplin anak kelompok B TK Insan Kamil Kab. Halmahera Selatan. Hal ini sejalan dengan penelitian yang pernah dilakukan sebelumnya oleh Lestari (2016:109) yang menyimpulkan bahwa upaya guru dalam meningkatkan kedisiplinan anak usia dini di taman kanak - kanak IT Az Zahra Kab. Lampung Selatan melalui 7 metode yaitu metode ketauladanan, metode pembiasaan, metode didaktif, metode pemberian nasihat, metode dialog, metode pemberian instruksi, dan metode pemberian hukuman.

\section{Penutup}

Berdasarkan analisis data dan pembahasan, maka dapat dijelaskan bahwa penerapan metode pembiasaan dapat meningkatkan perilaku kedisiplinan anak di taman kanak-kanak Islam Terpadu Insan Kamil pada Kelompok B1 Kabupaten Halmahera Selatan. Pada siklus I dari hasil observasi menunjukkan bahwa rata-rata $20 \%$ kemampuan anak belum berkembang dan 43,5\% kemampuan anak mulai berkembang sedangkan pada siklus II terjadi peningkatan, kemampuan anak berkembang sesuai harapan sebesar 56,27 \% dan berkembang sangat baik sebesar $26,75 \%$.

Dari hasil penelitian yang telah dilakukan, maka peneliti menyarankan, (1) Penerapan pembiasaan pada anak seharusnya dilakukan sejak dini agar anak menjadi terbiasa berperilaku disiplin dan menerapkannya secara rutin. (2) Selain melalui kegiatan spontan, guru dapat menempelkan gambar-gambar kebiasaan baik di dalam kelas sehingga anak dapat mencontohnya tanpa harus menegur anak. (3) Pembiasaan kepada anak dapat pula dilakukan guru melalui keteladanan yang ditunjukkan pada setiap tindakan. (4) Guru hendaknya lebih kreatif dan aktif dalam mengembangkan teknik atau metode untuk meningkatkan kedisiplinan anak usia dini bertujuan agar anak tidak mudah bosan dan jenuh.

\section{Daftar Pustaka}

Afrizal, Jamrad. 2010. Pembinaan Disiplin Kelas Bagi Siswa Taman Kanak-Kanak. Online. Diakses pada tanggal 2 September 2017. http://www.scribd.com/doc/.../18120772pembinaan-disiplin-kelas-1/.

Amin, M Maswardi. 2015. Pendidikan Karakter Anak Bangsa. Yogyakarta: Hak Cipta.

Departemen Pendidikan Nasional. 2007. Pedoman Pembelajaran Bidang Pengembangan Pembiasaan di Taman Kanak-Kanak. Jakarta: Dirjen Dikdasmen. 
Hasnida. 2014. Analisis Kebutuban Anak Usia Dini. Jakarta: Luxima.

Ihsani, Kurniah, Suprapti. 2018. Hubungan metode pembiasaan dalam pembelajaran dengan disiplin anak usia dini. Jurnal Ilmiah Potensia. Vol. 3 (1), 50-55

Lestari, Sri Rahayu. 2016. Upaya Guru Dalam Meningkatkan Kedisiplinan Anak Usia Dini Di Taman Kanak-Kanak. It Az Zahra Kecamatan Jati Agung Lampung Selatan Tabun Pelajaran 2016/2017. Skripsi. Pendidikan Guru Raudhatul Athfal: Lampung Selatan.

Purwanto, M. Ngalim. 1993. Ilmu Pendidikan Teoritis dan Praktis. Bandung: Remaja Rosdakarya

Syarbini, Amirulloh. 2014. Model Pendidikan Karakter dalam Keluarga. Jakarta : PT Elex Media Komputindo.

Yusuf, Syamsu. LN. 1993. Psikologi Perkembangan Anak dan Remaja. Bandung: Remaja Rosdakarya. 